\title{
Kadın Turist Rehberlerinin Karşılaştıkları Sorunların Belirlenmesine Yönelik Bir Araştırma
}

\section{Derya DEMIRDELEN ALRAWADIEH ${ }^{1}$}

\section{Özet}

$\mathrm{Bu}$ çalışmanın amacı, kadın turist rehberlerinin yaşadığı sorunları ve zorlukları ortaya koymak ve sorunlara yönelik çözüm önerileri sunmaktır. Bu kapsamda çalışmada nitel araştırma yöntemi kullanılarak yarı yapılandırılmış görüşmeler yapılmıştır. Toplamda 19 kadın turist rehberine ulaşılmıştır. Görüşme sonunda veriler, içerik analizine tabi tutulmuştur. Elde edilen bulgulara göre, kadın turist rehberlerinin mesleğinde karşılaştı̆̆ı sorunlar dört kategoride sınıflandırılmıştır. Bunlar; (i) cinsiyetten kaynaklı zorluklar, (ii) mesleğin doğası gereği yaşanan sorunlar, (iii) hizmet sağlayıcılar ile ilgili sorunlar ve (iv) turistlerle yaşanan sorunlardır. Sonuç olarak, kadın turist rehberlerinin ayırt edici sorunlara sahip olduğu belirlenmiş olup, bu sorunlara yönelik çözüm önerileri sunulmuştur. Bu kapsamda, başta seyahat acentaları olmak üzere turizm sektöründe yer alan tüm paydaşlara verilecek eğitimler, paydaşlar arasındaki yakın işbirliği, kadın rehberlere yönelik her türlü ayrıma veya farklı davranışa yönelik çeşitli düzenlemelerin ortaya konulması gibi öneriler geliştirilmiştir.

Anahtar Kelimeler: Turist rehberliği, Kadın çalışanlar, Mesleki sorunlar

JEL Kodu/Code: L83, Z30

\section{Understanding the Challenges Faced by Female Tour Guides}

\section{Abstract}

The aim of this study is to highlight the challenges and difficulties faced by female tour guides and suggest solutions. For this purpose, a qualitative research approach using semi-structured interviews was adopted. A total of 19 female tour guides were reached and interview data were then content analyzed. According to the findings, the challenges faced by female tour guides were classified into four categories. These were labelled as (i) gender-based challenges, (ii) challenges inherently associated with the job of tour guiding, (iii) challenges associated with service providers, and (iv) challenges associated with tourists. In sum, it has become clear that female tour guides have distinctive challenges and therefore, it is important to address these challenges. In this vein, the study highlights the need for trainings oriented toward different stakeholders within the sector, especially travel agencies. Close cooperation between stakeholders and enacting regulations against any form of discrimination towards female guides also appear to be imperative.

Key Words: Tour guiding, Female employees, Professional challenges

Referans/Citation: Demirdelen Alrawadieh, D. (2021). Kadın turist rehberlerinin karşılaştıkları sorunların belirlenmesine yönelik bir araştırma, Journal of Hospitality and Tourism Issues, Vol. 3, No.1, 1-15.

\footnotetext{
${ }^{1}$ Dr. Öğr. Üyesi, İstanbul Ayvansaray Üniversitesi, Seyahat, Turizm ve Eğlence Hizmetleri Bölümü, Türkiye, deryademirdelen@ayvansaray.edu.tr. Orcid ID: 0000-0002-7554-2256.
} 


\section{GİRIŞ}

İş yaşamında kadınlar, mesleki anlamda hâlâ bazı engellerle karşılaşmaktadır. Bu durumun ortadan kaldırılabilmesi ve kadının gerek toplumsal gerekse mesleki anlamda söz sahibi olabilmesi yönünde bazı stratejiler ortaya konulmakta ve kadınlara yönelik ayrımcılığın ortadan kaldırılması amaçlanmaktadır. Sürdürülebilir Kalkınma Amaçları'na göre (Sustainable Development Goals), Birleşmiş Milletlere üye ülkelerin 2030 yılının sonuna kadar hedefleri arasında toplumsal cinsiyet eşitliği de yer almaktadır (United Nations, 2021). Kadınların iş yaşamında karşılaştıkları çeşitli engelleri ortadan kaldırmaya ve cinsiyet ayırt etmeksizin iş yaşamına girmesi yönündeki gelişmelere karşın, Türkiye'de kadınların istihdam oranı, erkeklerin oranının neredeyse yarısı kadardır (TÜİK, 2021). Bu durumun nedenleri ve sonuçlarının araştırılması Türkiye'deki cinsiyet eşitliğini sağlamak ve sürdürülebilir kalkınma amaçlarına ulaşmak açısından oldukça önemlidir.

Öte yandan, turizm sektörü içerisinde en önemli paydaşlardan biri olan turist rehberleri, sektörel başarı için öncü ve etkin bir rol üstlenmektedir (Cetin \& Yarcan, 2017). Turist rehberlerinin etkin rolüne karşın, mesleki anlamda birçok sorun yaşadığı ve zaman zaman bu sorunların çözüme kavuşmadığ1 görülmektedir (Arslan \& Şimşek, 2018; Köroğlu vd., 2020). Mesleğin sorunlarına, bir de cinsiyete dayalı ayrım girdiğinde, kadın turist rehberleri için bu sorunlar daha zorlayıcı ve yıpratıcı bir hâl almaktadır (Alrawadieh vd., 2021).

Emek-yoğun olan turizm sektörü, kadın gücüne önemli ölçüde dayanmaktadır (Cave \& Kilic, 2010). Özellikle, bu meslekte yer alan kadın çalışanlar sayıca az değildir. Türkiye'de eylemli kadın turist rehberleri, toplam oranın \%30'unu oluşturmaktadır (TUREB, 2021). Kadın çalışanların önemine birçok bilim dalında, iş kolunda ve turizm araştırmalarında sıklıkla değinilmiştir. Ancak turist rehberliği açısından alan yazında sınırlı bilgiye ulaşılmaktadır. $\mathrm{Bu}$ anlamda bu çalışma, kadınların meslekteki önemi doğrultusunda değerli görülmektedir.

Çalışmanın teorik katkısı; kadın turist rehberlerinin şikâyetlerini anlamak ve olası şikâyetlerin ortadan kaldırılmasına yönelik çözüm önerileri sunmaktır. Bu çalışma; özellikle kadın turist rehberlerinin sorunları konusunda yapılan görüşmelerle sınırlı alan yazına katkı sağlamakta, sorunların çözümüne yönelik önerilerle birlikte yol gösterici olmakta ve turizmin tüm paydaşlarına yönelik öneriler sunması açısından önem arz etmektedir.

\section{KAVRAMSAL ÇERÇEVE}

\subsection{Turist Rehberliği Mesleğindeki Zorluklar}

Turizm hizmetleri içerisinde yer alan turist rehberliği, sektörün vazgeçilmez dinamiğidir. Şüphesiz, turist rehberlerini bu kadar önemli kılan; hizmet kalitesi ve deneyimini etkileme (Liljeblad, 2020), ülke tanıtımı ve imajına katkı sunma (Dinçer \& Demirdelen, 2019) ve organizasyonel başarıyı sağlama (Mackenzie \& Raymond, 2020) gibi konularda öncü olması ve sektöre 1şık tutmasıyla açıklanabilir. Mesleğin bu denli önemine karşın, zorlu doğası bu meslekte çalışan kişiler açısından zaman zaman yorucu, yıpratıcı ve zorlayıcı olabilmekte (Chen \& Chang, 2020) ve mesleği icra ederken bir takım sorunlara yol açabilmektedir.

Turist rehberliğinin doğası, turistlerle uzun ve yakın etkileşimi içerir (Alrawadieh vd., 2020). Bir tur boyunca rehberin uzun süre turistlerle beraber olması (Hwang \& Lee, 2019), mesleğin fiziksel yükünün yanında duygusal açıdan da zorlayıcı yönünü ortaya koymaktadır. Aynı zamanda sektörün mevsimsel özellik göstermesi (Cetin \& Yarcan, 2017), insan ilişkilerinin oldukça yoğun olması (Akdu 
\& Akdu, 2016), iş saatlerinin düzensiz olması, çalışma koşullarının zorlu olması gibi pek çok mesleğe dair özellik, turist rehberliğinin zorlu doğasını açıklamaktadır (Dumanlı \& Köroğlu, 2018). Fiziksel ve duygusal açıdan zorlayıcı olan bu durum, mesleki sorunların tespit edilip, olası çözüm önerilerini ortaya koymayı gerekli kılmaktadır.

Turist rehberlerinin sorunlarını ortaya koymak amacıyla gerek ulusal (Karacaoğlu \& Sert, 2018; Büyüktepe vd., 2019; Karamustafa \& Kılıçhan, 2019), gerekse uluslararası (Nyahunzvi \& Njerekai, 2013; Ababneh, 2017) alan yazında çalışmalar hız kazanmaktadır. Karacaoğlu ve Sert (2018), kaçak rehberlik faaliyetleri yapılmasının (kokartsız olarak), turist rehberlerinin en büyük sorunlarından biri olduğunu vurgulamıştır. Sonrasında ise seyahat acentalarının ücret politikalarını eleştirmiş ve meslek yasasının rehberleri korumadığını ifade etmiştir. Güzel ve arkadaşları (2014), turist rehberlerinin mesleki engelleri üzerine yaptığı çalışmada, mesleki ve sektörel engellerin varlığını ortaya koymuştur. Batman (2003), çalışmasında yasal sorunların yanı sıra turist rehberlerinin otel, seyahat acentası, ulaştırma işletmeleri, turist grupları ve müzelerle de yaşadığı sorunlara değinmiştir. Büyüktepe ve arkadaşları (2019), çalışmasında turist rehberlerinin sosyal, fiziki, kişisel ve yönetsel sorunlarını ortaya koymuştur. Karamustafa \& Kılıçhan (2019) ise turist rehberlerinin mesleğe ait sorunlarını vurgulamış; sonrasında konaklama, seyahat, ulaştırma işletmeleri gibi paydaşlarla yaşanan sorunları ortaya koymuştur.

Mesleki sorunların ortaya çıkarılması, olumsuz sonuçların azaltılması için de önemli bir etkendir. Çünkü kültür elçisi olan turist rehberliği mesleği; stresin (Mackenzie \& Kerr, 2013; Akdu \& Akdu, 2016), duygusal emeğin (Alrawadieh vd., 2020), tükenmişliğin (Akdu \& Akdu, 2016), işten ayrılma niyetinin (Wong \& Wang, 2009) ve iş-aile çatışmasının (Lin vd., 2019) yüksek olduğu bir iş alanıdır. Sayılan tüm bu olumsuz durumların ortadan kaldırılabilmesi için öncelikle turist rehberlerinin yaşadığı problemleri belirlemek, yaşanılan problemleri en aza indirgemek ve olası çözüm önerileriyle birlikte mesleği desteklemek gerekmektedir. Çünkü ülkelerin temsilcisi olma görevi üstlenen turist rehberlerinin, işini daha iyi yapması ve sektörde daha aktif olabilmesi için var olan sorunları belirlemek önem arz etmektedir (Karacaoğlu \& Sert, 2018).

\subsection{Kadın Turist Rehberlerinin Meslekte Yaşadığı Zorluklar}

Cinsiyet eşitsizliği günümüzde küresel bir sorun olmaya devam etmektedir (Alrawadieh vd., 2021). Gerek dünyada gerekse Türkiye'de her geçen gün kadının iş hayatına girmesi ve istihdam oranı hızla artsa da, bu artışın erkek çalışanlara nazaran daha az olduğu bilinmektedir (TÜİK, 2021). Bu durum, Türkiye gibi gelişmekte olan ülkeler açısından değerlendirildiğinde, özellikle turizm gibi hizmet alanlarında kadın istihdamının artmasına yönelik çeşitli plan, politika ve uygulamaların yürütülmesinin gerekliliği ortaya çıkmaktadır (Yetiş \& Çalışkan, 2020).

Kadınlar, turizm hizmetlerinde hem üretici hem de tüketici olmasına rağmen, turizm araştırmalarında cinsiyete dayalı araştırmalar sınırlı sayıdadır. Turizm ve cinsiyet arasındaki ilişkinin 90'lı yılların ortalarına doğru ilgi görmeye başlaması, turizmde cinsiyet araştırmalarının da temelini atmış oldu (Figueroa-Domecq vd., 2015). 1990'ların ortalarından itibaren ise, turizm sektöründe kadın çalışmalara yönelik araştırmalar hızla artış göstermiştir (Wang \& Xu, 2018). Bu durum, turizmin, özellikle kadınlara geniş bir istihdam firsatı yaratmasıyla ilgili olabilmektedir (Hall vd., 2003; FigueroaDomecq vd., 2015). Hatta Aracı \& Koçak'a göre (2014), kadınlar iş hayatında her ne kadar dezavantajlı gruplardan biri olarak kabul edilse de, turizm hizmetlerinde hem kadın hem de erkekler, istihdama ciddi katkı sağlamaktadır. Ancak, kadın ve erkek çalışanlar aynı işi yapıyor olsa bile, kadınların turizm sektöründeki istihdam alanlarında kalmaları ve işi sürdürülebilir kılmaları zaman zaman erkek çalışanlara göre daha zor olabilmektedir (Wang \& Xu, 2018). 
Muñoz-Bullón'a göre (2009), erkekler nispeten yüksek nitelik seviyeleri gerektiren turizm işlerinde (özellikle yüksek ücretlerin alındığı yerlerde) kadınlardan daha fazla yer almaktadır. $\mathrm{Bu}$ nedenle, turizm sektöründe mesleki seviyeler arasında önemli bir ayrım yapıldığı vurgulanmıştır. Sektör içinde kadınlar daha fazla duygusal emek gerektiren bir iş alırken, erkekler genellikle daha profesyonel ve yönetsel roller üstlenmektedir (Wang \& Xu, 2018). Üstelik turizm sektöründe kadınların cam tavan engelleriyle karşılaşma olasılığı oldukça yüksektir (Yazıt \& Demirdelen, 2018).

Diğer taraftan, turizm hizmetlerinin can damarlarından biri olan turist rehberliği, mesleğin genel yapısı itibariyle kadın işi veya erkek işi gibi bir ayrımı gerektirmeyen meslekler arasında görülmektedir. Türkiye'de çalışan kadın turist rehberleri, erkek turist rehberlerine nazaran daha az olsa da (TUREB, 2021), turist rehberliği kadın istihdamı açısından önemli mesleklerden biridir. Ancak, kadın turist rehberleri ile erkek turist rehberleri arasında sorunlar kısmında bir takım farklılıklar oluşabilmektedir. Bu durum, mesleğe özgü genel sorunların yanı sıra kadınlara has mesleki problemlerin varlığından da kaynaklanmaktadır.

Kadın turist rehberlerinin sorunlarını ele alan sınırlı çalışma bulunmaktadır. Arslan \& Şimşek (2018) kadın turist rehberlerinin mesleki sorunları üzerine yapmış olduğu çalışmada, genel sorunların yanı sıra (turistlerle, meslektaşlarla, seyahat acentasıyla yaşanan sorunlar gibi), cinsiyete bağlı olarak kadın turist rehberlerinin yaşadıkları sorunların da yoğun olduğunu ifade etmiştir. Onlara göre bu durum, erkek egemen toplumun bir sonucudur. Zengin ve arkadaşları (2014), kadın turist rehberlerinin sorunlarının cinsel taciz, kaba davranış, ailesel ve personelle ilgili sorunlardan kaynaklandığını ifade etmiştir. Güncel bir araştırma ise (Köroğlu vd., 2020) kadın turist rehberlerinin yaşadıkları sorunları ortaya koyarken, genel sorunların yanı sıra kadının doğasından kaynaklanan sorunların varlığına işaret etmiştir.

Alan yazındaki bu araştırmalar kadın turist rehberlerinin sorunlarının anlaşılması konusunda önemli bilgiler aktarmaktadır. Ancak nicelik açısından alandaki çalışmalar, mevcut durumu iyileştirecek ve seyahat endüstrisindeki politikaları etkileyecek kadar yeterli değildir. Bu çalışma, gerek teorik alan yazını zenginleştirmesi, gerekse uygulamaya yönelik önerilerde bulunması bakımından önem taşımaktadır.

\section{YÖNTEM}

Çalışmanın amacı; kadın turist rehberlerinin mesleğinde yaşadığı sorunları ve zorlukları ortaya koymaktır. Çalışma, nitel araştırma yöntemine dayanmakta olup, veri toplama aracı olarak görüşme tekniğinden yararlanılmıştır. Her ne kadar turist rehberliği mesleğinin zorlu yapısı ve doğası itibariyle cinsiyete bakılmaksızın bazı zorluklar yaşanıyor olsa da (Batman, 2003; Güzel vd., 2014; Karamustafa \& Kılıçhan, 2019), özellikle kadın çalışanların dezavantajlı gruplar arasında değerlendirilmesi (Umutlu \& Öztürk, 2020) yaşanan sorunların boyutunu değiştirebilmektedir. Bu nedenle, araştırmada kadın ve erkek turist rehberlerinin sorunları arasında farklılıklar bulunacağı göz önüne alınarak, araştırma kapsamına sadece kadın çalışanlar dâhil edilmiştir. Bu kapsamda, katılımcılar için ön koşul; kokartlı olmak, eylemli olmak ve en az bir yıl profesyonel turist rehberi olarak çalışmış olmak olarak belirlenmiştir.

Veriler yarı yapılandırılmış görüşme formu kullanılarak toplanmıştır. Kadın turist rehberlerinin sorunlarını anlamaya yönelik oluşturulan sorular geniş bir alan yazın taramasına dayanılarak oluşturulmuştur (Yagil, 2008; Min, 2014; Figueroa-Domecq vd., 2015; Ferguson \& Alarcon, 2015; Arslan \& Şimşek, 2018; Ram, 2018). Bu kapsamda, görüşme sorularının birinci kısmında yaş, medeni 
durum, eğitim durumu gibi demografik bilgiler yer alırken; ikinci kısmında kadın turist rehberlerinin sorunlarını anlamaya yönelik açık uçlu sorular bulunmaktadır. Özetle, katılımcıların turist rehberliği açısından mesleki deneyimlerinden bahsetmeleri istenmiştir. Ardından da mesleki hayatlarında karşılaştıkları sorunları belirtmeleri talep edilmiştir. Belirtilen sorunları daha iyi anlamak için derine inen (probing) sorular da sorulmuştur. Çalışma kapsamında toplamda 19 kadın turist rehberiyle görüşülmüş ve her görüşme yaklaşık 25 dakika sürmüştür. Veriler, yeterli doygunluğu ulaştığ1 için bu say1 yeterli görülmektedir (Glaser \& Strauss, 1967). Veri toplama süreci, Nisan 2019 ve Haziran 2019 tarihleri arasında beş haftalık süreyi kapsamaktadır. Sonraki süreçte yapılan görüşmeler yazıya dökülmüş ve veriler içerik analizine tabi tutulmuştur. İçerik analizinde, veriye dayalı (tümevarım) ve teoriye dayalı (tümdengelim) karma bir yaklaşım benimsenmiştir (Dinçer \& Alrawadieh, 2017). Bu yaklaşım sayesinde, konu ile ilgili mevcut alan yazın göz ardı edilmeden, elde edilen verilerden ortaya çıkan kategori ve temaların doğalca oluşmasına imkân sağlanmıştır (Patton, 1990). İçerik analizinin güvenirliğini sağlamak için, Berg (2001) ve Neuman'ın (2003) önerdiği gibi, veriler iki bağımsız araştırmacı tarafından (biri yazar ve bir diğeri turist rehberliği ile ilgili konularda çalışan bağımsız bir araştırmacı olmak üzere) analiz edilerek, oluşturulan son çerçeve üzerinde uzlaşmaya varılmıştır.

Hâlihazır araştırmada kullanılan veriler, daha kapsamlı bir projenin parçası olup (Alrawadieh \& Demirdelen Alrawadieh, 2020) elde edilen zengin içerik ve anlaşılan geniş kapsam kadın turist rehberlerinin sorunlarını ele alan bu araştırmanın yapılmasını teşvik etmiştir. Son olarak, katılımcıların kimliği korunarak kadın turist rehberlerinin yaşadığı sorunları daha net anlayabilmek ve veri analizinin güvenirliğini arttırmak adına doğrudan alıntılara da yer verilmiştir (Elo \& Kyngäs, 2008).

\section{BULGULAR}

Kadın turist rehberleriyle yapılan görüşmeler neticesinde elde edilen demografik bulgular (yaş, cinsiyet, eğitim, medeni durum) ve mesleki bulgular (kokartını aldığı dil, çalışma deneyimi, çalışma şekli) aşağıdaki tabloda gösterilmektedir.

Tablo 1. Kadın turist rehberlerinin demografik özellikleri

\begin{tabular}{lclc}
\hline Yaş & \multicolumn{3}{c}{ Kokartını Aldığı Dil } \\
\hline 28 ve öncesi & 1 & Bir dil & 15 \\
\hline $29-39$ & 6 & İki dil & 3 \\
\hline $40-49$ & 11 & Üç dil ve fazlası & 1 \\
\hline $50+$ & 1 & Çalışma Deneyimi & 5 \\
\hline Eğitim & & $1-3$ yıl & 1 \\
\hline Lise & 1 & $4-10$ yıl & 4 \\
\hline Önlisans & 3 & $11-15$ yıl & 5 \\
\hline Lisans & 11 & $16-20$ yll & 4 \\
\hline Lisansüstü & 4 & 20 yıldan fazlası & 6 \\
\hline Medeni Durum & & Çalışma Şekli & 13 \\
\hline Evli & 6 & Seyahat ac. bağlı \\
\hline Bekâr & 13 & Serbest & \\
\hline
\end{tabular}

Tablo 1'de gösterildiği gibi katılımcıların çoğu orta yaş grubunda, seyahat acentasından bağımsız çalışan, bekâr kadın turist rehberleridir. Yarısından fazlası lisans mezunudur. Hatta yüksek lisans derecesine sahip olan dört kadın turist rehberi de olduğundan, katılımcıların genel eğitim seviyelerinin yüksek olduğu sonucuna varılmaktadır. Katılımcıların büyük çoğunluğu (8 kişi), üniversitelerin turist rehberliği programından mezun olmuş, bir kişi ise turizm işletmeciliği programından mezun olmuştur. Diğerleri ise; turizm ve turist rehberliği ile ilgili olmayan dil, ekonomi ve işletme gibi farklı bilim dallarından mezun olmuşlardır. Katılımcıların çoğunluğunun 10 yıldan fazla iş deneyimi bulunmaktadır. Katılımcıların kokart dillerinin başında tek dil gelirken; birden fazla dil ile kokartını 
alan dört rehber bulunmaktadır. Tek dilden lisanslı olanların büyük çoğunluğu İngilizce, bunu takiben İspanyolca ve Yunanca dilini kullanmaktadır.

Yapılan içerik analizine göre, kadın turist rehberlerinin en çok karşılaştıkları sorunlar, dört kategoriye ayrılmıştır. Bunlar; Şekil 1'de gösterildiği gibi cinsiyetten kaynaklı zorluklar, mesleğin doğası gereği yaşanan sorunlar, hizmet sağlayıcılar ile ilgili sorunlar ve turistlerle yaşanan sorunlardır.

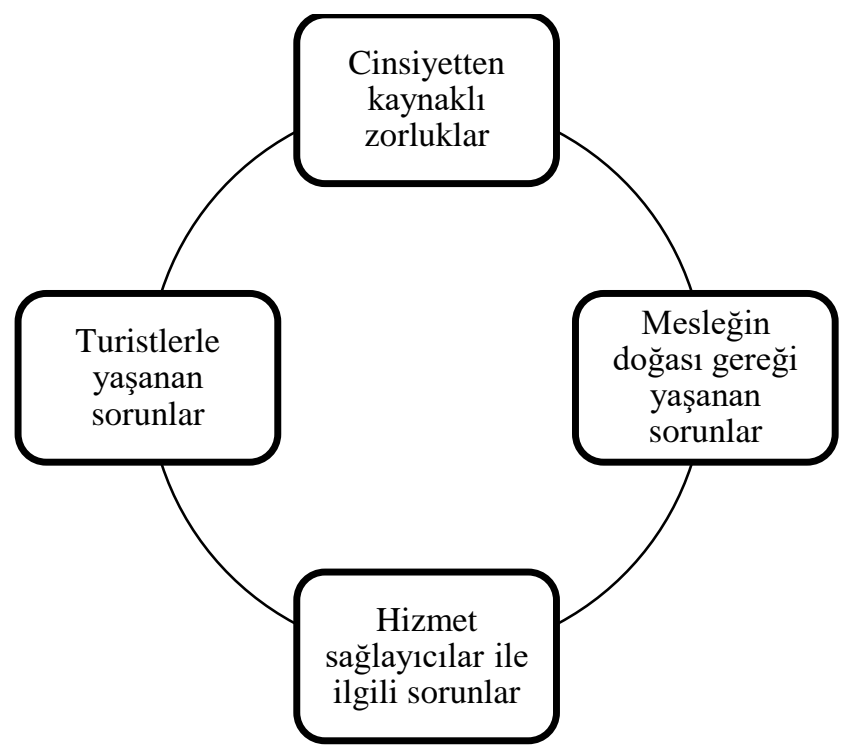

Şekil 1. Kadın turist rehberlerinin karşılaştıkları sorunlar

\section{Cinsiyetten kaynaklı zorluklar}

Katılımcılardan elde edilen bulguya göre, yaşanılan sorunların başında cinsiyetten kaynaklı zorluklar gelmektedir. Hatta hemen hemen tüm katılımcilar meslekte cinsiyetten kaynaklı zorlukların yaşandığını belirtmişlerdir. Günümüz dünyasında her ne kadar cinsiyet ayrımcılığının azaldığı ifade edilse de, hala birçok meslekte ve insan emeğinin yoğun olarak yaşandığı turizm hizmetlerinde de cinsiyetten kaynaklı zorluklar yoğun bir şekilde hissedilmektedir (Ferguson \& Alarcon, 2015).

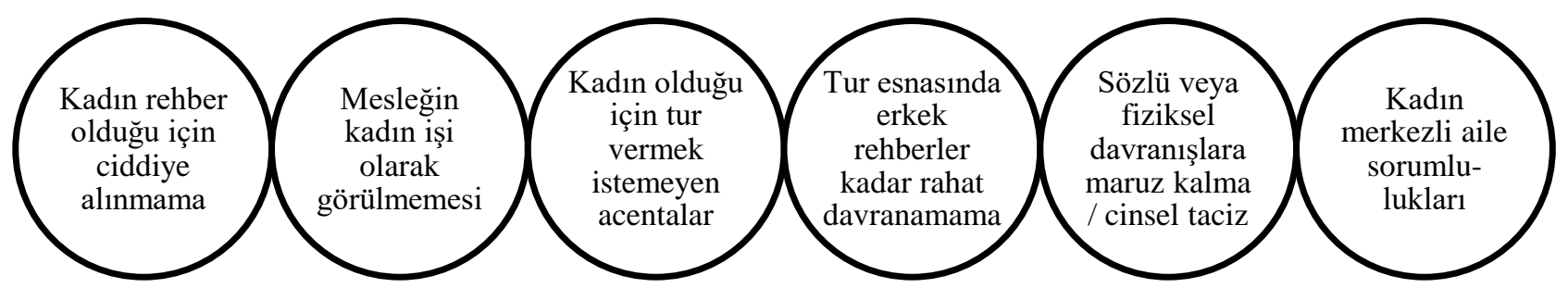

Şekil 2: Cinsiyetten kaynaklı zorluklara ilişkin ortaya çıkan temalar

Özellikle turist rehberliği gibi yüz yüze ilişkinin yoğun olduğu mesleklerde zaman zaman kadınlar, erkeklere nazaran dezavantajlı grup olarak algilanabilmektedir (Wang \& Xu, 2018; Koc, 2020). Bu kapsamda, katılımcılar en çok kadın rehber olduğu için ciddiye alınmamaktan, mesleğin kadın işi olarak görülmemesinden, kadın olduğu için tur vermek istemeyen acentaların varlığından şikâyet etmektedir. Benzer bulgulara kadın turist rehberleri üzerine yazılan bazı çalışmalarda da rastlanmaktadır (Köroğlu vd., 2020). Örneğin;

"Birçok zaman kadınlar bu işi yapamazmış gibi bir algı olabiliyor insanlarda, tura gelen misafirlerde de (şu an 35 yaşındayım ama 20li yaşlarda da aynıydl) hem kadınsınız hem yaşınız çok genç, siz bizi nasıl gezdireceksiniz, sanki turistler erkek rehberlere daha çok güveniyorlar gibi bir algı var. Erkek 
rehber daha otoriter gibi görünüyor, erkek rehber 'saat 8'de buluşma yerinde olunsun' dediğinde herkes 8'de orada oluyor, otorite daha kolay sağlanıyor, kadın rehber bunu dediğinde birçok kişi çok önemsemiyor". K.9

Wang \& Xu'ya göre (2018) kadın çalışanlar, erkek meslektaşlarına göre zaman zaman dezavantajlıdır. Birçok meslekte olduğu gibi turizm hizmetlerinde de kadın çalışanların, hizmet sunumu esnasında cinsiyet rolü beklentilerine uygun davranmaları beklenir (Koc, 2020). Özellikle erkek çalışanların güven, güç, hedef odaklılık, liderlik gibi konularda daha uygun olduğunu düşünen bireyler olduğundan, bu durum kadının iş için yetersiz veya uygunsuz görülmesi anlamına gelmektedir (Segovia-Pérez vd., 2019). Turizm hizmetlerinde özellikle erkek yöneticilerin, kadının işini iyi yapacağına inanmaması ve erkekler kadar başarılı olamayacağı inancı (Yazıt \& Demirdelen, 2018) bir takım sorunların doğmasına neden olmaktadır. Turist rehberliği açısından bu durum özellikle turu veren acentanın cinsiyet odaklı davranışlarıyla sonuçlanabilmektedir. Örneğin, kadın olduğu için tur vermek istememe, tur için erkek rehberleri seçme gibi ayrımcılık, kadın turist rehberleri açısından zorlayıcı ve yıpratıcı sonuçların ortaya çıkmasıyla sonuçlanabilmektedir. Örneğin;

"Çok birebir olmasa da acentaların biraz cinsiyetçi davrandığını söyleyebilirim. Mesela erkeklere daha problemsiz iş yaptırdıklarını düşünen çok operasyon müdürü olduğunu düşünüyorum. Erkeğe öncelik vermeleri, erkek rehberin işi daha iyi daha sorunsuz yapmast gibi algıları var ve bu biraz cinsiyetçi davranmak oluyor. Bu beni çok rahatsız ediyor". K.16

Sayıca daha az olsa da, diğer zorluklar arasında; tur esnasında erkek rehberler kadar rahat davranamama, sözlü veya fiziksel davranışlara ve hatta cinsel tacize maruz kalma sayılmaktadır. Özellikle kadın turizm çalışanlarının sözlü veya fiziksel tacize uğraması konusu ortaya çıkabilecek sorunlar açısından yıpratıcı olmasına rağmen, alan yazında konuyla ilgili araştırma alanları bakir kalmıştır (Alrawadieh vd., 2021). Turizm sektöründe cinsiyet araştırmalarına yönelik bir çalışmada (Figueroa-Domecq vd., 2015) kadın çalışanların uğradığı taciz ile ilgili konuların tamamen ihmal edilmiş bir çalışma alanı olduğu ifade edilmektedir. Ancak son zamanlarda konunun önemi doğrultusunda cinsel tacizin turist rehberlerinin iş tatmini ve iyi oluşuna zarar verdiği sonucu da ortaya çıkmıştır (Alrawadieh vd., 2021). Kadın turist rehberlerinin sorunları üzerine yapılan çalışmalarda da genel sorunlar arasında cinsel taciz vurgulanmıştır (Zengin vd., 2014; Köroğlu vd., 2020). Arslan \& Şimşek (2018), kadın turist rehberlerinin turistlerle arasında sözlü taciz yaşandığını ifade etmiştir. Bu kapsamda K.13 şu ifadeleri kullanmıştır:

"Yani anlatması biraz zor ama rehberlik çok sosyal insanların yaptı̆̆ bir meslek grubu olduğu için birçok insan sizin çok rahat olduğunuzu düşünüyor ve sizin üzerinizde sürekli şansını deniyor, 'akşam dışarı çıkalım mı', 'bir şeyler içelim mi' gibi [...]"

Yine bazı kadın turist rehberleri kadın merkezli aile sorumluluklarının zorluklarını ve bu durumun mesleki sorunlara yol açtığını belirtmiştir. Chen \& Chang (2020) mesleğin aktif bir çalışma alanı olmasının, kadın turist rehberlerinin özel, ailevi ve sosyal yaşamları üzerinde önemli bir etkisi olduğunu belirtmektedir. Arslan \& Şimşek (2018) ise çocuk sahibi kadın turist rehberlerinin çok fazla konaklamalı ve uzun süreli turlara çıkamadıklarını, aksine günübirlik ve kısa süreli turları tercih ettiğini ifade etmiştir. Köroğlu ve arkadaşları (2020) ise kadın turist rehberlerinin aile yaşamındaki zorluk ve ev yaşamındaki düzensizlik gibi kadın merkezli sorunları olduğunu belirtmektedir. Örneğin; K.9 “...Kadın olarak evde daha fazla sorumluluklarımız olabiliyor, evli olma ve çocuk bakımı gibi, bu nedenle uzun turlara, haftallk turlara gitmemiz biraz daha zor oluyor” şeklinde ifade etmiştir. 
İlginçtir ki, yapılan görüşmeler neticesinde sadece bir katılımcının cinsiyetten kaynaklı zorluk yaşamadığı ve hatta kadın olmasının mesleki açıdan dezavantaj değil, aksine bir avantaj olduğunu vurgulamıştır. Konuyla ilgili olarak K.10 şu şekilde ifade etmiştir: "Erkek rehberle kadın rehber arasında zorluk pek yok, fark yok diyebilirim hatta biz kadınız diye daha hassas davrandıklarını söyleyebilirim".

\section{Mesleğin doğası gereği yaşanan sorunlar}

Turist rehberliği, uzun ve yorucu çalışma saatleri ile fiziksel gücün yüksek olduğu bir iş kolu olduğundan, zorlu mesleklerden biri olarak kabul edilmektedir (Alrawadieh vd., 2020). Bu durum, meslekte çalışan tüm bireyler için geçerli olsa da (Karamustafa \& Kılıçhan, 2019; Büyüktepe vd., 2019), kadının toplumdaki rolü itibariyle (ev, eş ve çocuk sorumlulukları gibi) daha zorlu geçebilmektedir.

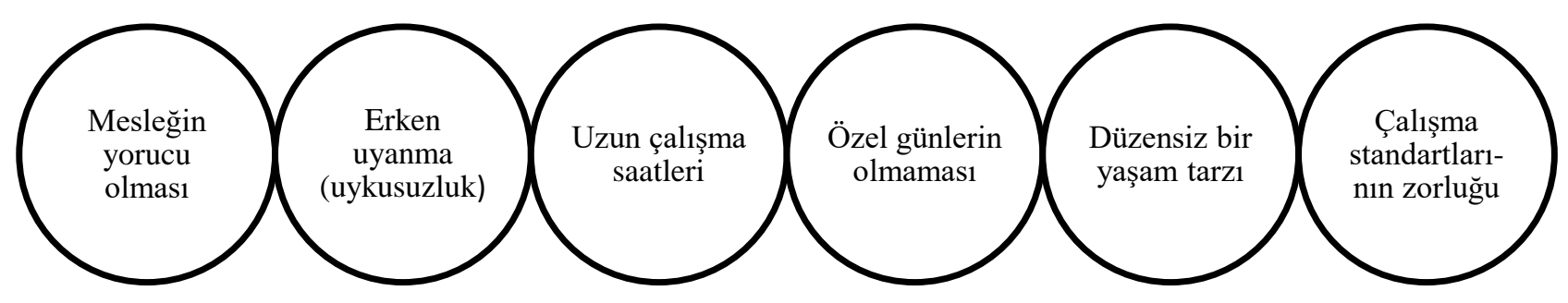

Şekil 3: Mesleğin doğası gereği yaşanan sorunlara ilişkin ortaya çıkan temalar

Özellikle, uzun süre aileden ve evden uzak olmak kadın rehberler açısından birçok sorunu beraberinde getirmektedir. Lin ve arkadaşları (2019), uzun süre evden uzakta olan turist rehberlerinin iş-aile çatışması yaşama olasılığının daha yüksek olduğunu ifade etmektedir. Chen \& Chang ise (2020) kadın rehberlerin genellikle evlendikten sonra işlerini değiştirdiğini ifade etmektedir. Bu durum, mesleğin doğasını açıklasa da, özellikle kadının iş ve aile sorumluluklarının erkeklere oranla daha fazla olmasıyla açıklanabilir. Örneğin;

“...Evinizden uzak olmanız, bayramları yakalayamamanız, erkekler de bunu yaşıyordur ama kadınlar daha duygusal o noktada. Daha soğukkanlı olmamız lazım sanırım”. K.4

Elde edilen bulgulara göre, mesleğin doğası gereği yaşanan sorunlar arasında; mesleğin yorucu olması, erken uyanma (uykusuzluk), uzun çalışma saatleri, özel günlerin olmaması, düzensiz bir yaşam tarzı, çalışma standartlarının zorluğu gibi sorunlar ortaya çıkmıştır. Büyüktepe ve arkadaşları (2019) mesleğin düzensiz çalışma saatlerinin olduğunu ve bu durumun turist rehberlerini olumsuz etkilediğini ifade etmiştir. Benzer bulgulara birçok çalışmada rastlanmaktadır (Karamustafa \& Kılıçhan, 2019; Köroğlu vd., 2020). Bu kapsamda K.1 görüşünü şu sözlerle ifade etmektedir: “...Uzun çalışma saatleri ve erken saatlerde uyanmak beni zorluyor...".

Turist rehberliği mesleği, insani ve sosyal ilişkilerin fazla olduğu mesleklerden biri olarak kabul edilmektedir. Şüphesiz bu durum emek yoğun özelliğinden ve kültür alışverişinin fazla olmasından kaynaklanmaktadır. Ancak zaman zaman turist rehberleri iş yaşamında ortaya çıkan sosyal ilişkilerine göre, özel yaşamında aynı tempoyu yakalayamamaktadır. Bu durum, aslında yine uzun çalışma saatleri gibi mesleğin doğası gereği yaşanan sorunlardan biri olarak ortaya çıkmaktadır. Bu kapsamda aşağıdaki ifade örnek olarak gösterilmektedir:

"Biz çok sosyal insanlarız ama asosyal gibi yaşıyoruz maalesef. Çünkü çok fazla kendimiz için ayırdığımız özel bir zaman yok. İşler çok yoğun devam ettiği için sadece aynı çevrede ve aynı milletlere kanalize olmuş durumdayız. Çok fazla sosyal yaşamıyoruz açıkçası, çok küçük bir çevremiz 
var, çok büyük gibi görünse de. Bu da insanı bazen rahatsı ediyor, çünkü gittiğimiz her yer sürekli aynı, anlattı̆̆ımız tarih değişmeyen bir tarih, hitap ettiğimiz millet hep aynı millet, yani kendimiz için ayırdiğımız çok fazla zaman yok. O yüzden sosyal asosyalleriz biz... ’. K.13

\section{Hizmet sağlayıcılar ile ilgili sorunlar}

Turizm hizmetleri konaklama, ulaştırma, yeme-içme, seyahat gibi çok kapsamlı ve çok geniş bir çalışma alanıdır. Bu kapsamda bir turun başarılı geçmesi, turda yer alan tüm hizmet sağlayıcılar arasındaki uyumla yakından ilişkilidir. Ancak zaman zaman hizmet sağlayıcılara yönelik bazı sorunlar ortaya çıkabilmektedir.

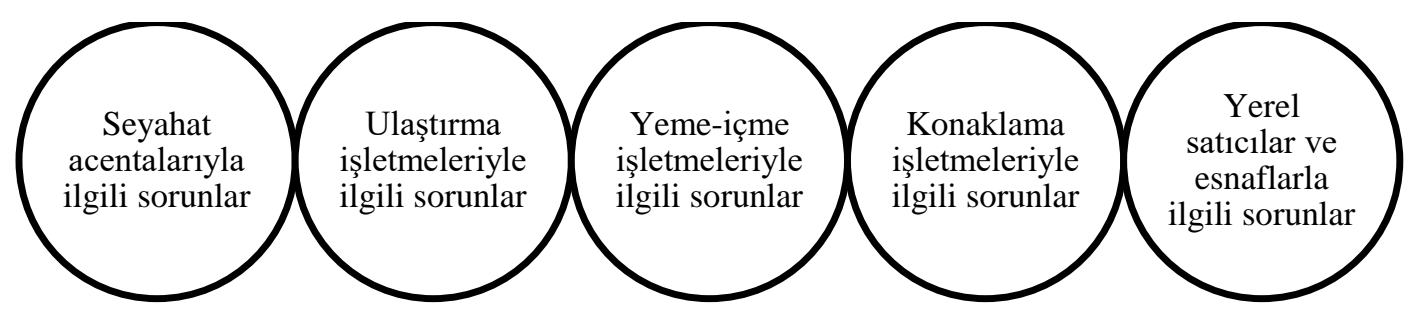

Şekil 4: Hizmet sağlayıcılar ile ilgili sorunlara ilişkin ortaya çıkan temalar

$\mathrm{Bu}$ kapsamda, elde edilen bulgular neticesinde, kadın turist rehberleri en çok seyahat acentalarıyla sorunlar yaşamaktadır. Bir turist rehberi, çalışma şekline bakılmaksızın (seyahat acentasına bağlı veya bağımsız), paydaşlar arasında en çok seyahat acentalarıyla yakın ilişki içerisindedir. Çünkü bir turist rehberine görevi ve yetkiyi veren işletmeler, seyahat acentalarıdır. Ancak zaman zaman bu yakın işbirliğinden doğan sorunlar, turist rehberleri açısından zorlayıcı olabilmektedir. Bu kapsamda, elde edilen bulgulara göre, seyahat acentalarının tur satışı için kadın turist rehberlerini zorladığı, zor bir anda rehberi korumadığı, karar verme yetkisini tamamen elinde bulundurarak rehberin hareket etme alanını kısıtladığı, turist rehberine yanlış bilgi vererek onu yanlış yönlendirdiği gibi sorunlar yaşandığı belirtilmiştir. Bu durumu K.4 şu şekilde ifade etmektedir:

“...Acentalar tarafindan tur satışı sırasında müşteriye yanlış bilgi verilmesi, bununla beraber yaşanan aksaklıklar en hoşlanmadığım durum. Çünkü bu durum bize yansıyor ve çok büyük sorunlar çıkabiliyor o noktada, acentacının daha bilgili tur satışı yapmaması en büyük şikayetimiz...”.

“Acenta ve rehber arasındaki ilişki en hoşlanmadiğım konular arasında. Çok fazla rehber olunca acentalar ellerindeki rehberi robotmuş gibi kullanıyorlar çok hızlı ve fazla olarak her şeyi sizden bekliyorlar, o yüzden yurtiçinde bağımsız çalışmamın en büyük sebebi acenta rehber arasındaki bu ilişki. Akşam grubu bırak, sabah grubu al esneklik payı yok, karar verme yetkisi bize bırakılmıyor (örneğin akşam yemeğini turist nerede almak isterse acenta bu esnekliği rehbere bırakmıyor, siz yolcuya bunu açıkllyorsunuz)...”. K.2

Turist rehberleri çok fonksiyonlu göreve sahip olduğundan, ulaştırma işletmeleri, yeme-içme işletmeleri, konaklama işletmeleri gibi paydaşlarla da çeşitli sorunlar yaşayabilmektedirler (Karamustafa \& K1lıçhan, 2019). Turizm deneyimlerine aracılık eden turist rehberlerinin (Mackenzie \& Raymond, 2020), paydaşlarla arasındaki ilişki çok önemlidir. Çünkü paydaşlarla yaşanacak olumsuz bir ilişki, turist rehberlerinin iyi oluşunu etkileyebildiği gibi, bu durumun turistlere yansıması ile onlara da negatif yönlü bir etki yapabilmektedir. Çünkü turist rehberleri ile ilgili sorunlar ele alınmadıkça, bu durum turistlerin hizmet kalitesi algısına etki edebilir ve turizm destinasyonunun imajına zarar verebilir (Ap \& Wong, 2001). Dahası, turizm sektörü, ziyaretçilerine kaliteli tur deneyimleri sağlamak için çabalamaktadır. $\mathrm{Bu}$ açıdan, hizmet sağlayıcılar ve paydaşların üzerine düşen görevi eksiksiz 
yapması ve ilişkilerin düzenli yürütülmesi için koordinasyonun sağlanması önemlidir. Paydaşlarla ilişkiler kapsamında örnek vermek gerekirse;

"Yeni karşılaştı̆̆ım şoförlerden bahsediyorum, her zaman gördüğüm beraber çalıştı̆̆ım şoförlerden değil, aynı şey garsonlar için de geçerli. Bize sarkanlar oluyor, terbiyesizlik yapanlar oluyor, saygısızlık yapan oluyor. Çünkü bir yerde kadın olduğunuz için sizi çok fazla ciddiye almıyorlar. Daha sert mizaçlı olmak gerekiyor, kadın olmanın en büyük dezavantajı budur belki de...”. K6

“Kadınlar zorluklar yaşıyorlar. Özellikle ekip arkadaşlarınız, başta şoförler, otelciler, halıcılar gibi hizmet sağlayıcıların bir kadın rehber olduğundaki tavırları zorlayıcı... Kadın rehber akşam da oturuyor, şarap da içiyor izlenimi oluyor, dolayısılla bu kadın rahattır gibi bakış atan şoförler oluyordu..." K.7

Yukarıda da anlatıldığı gibi bir turun sorunsuz işlemesinden sorumlu olan turist rehberleri turizm endüstrisindeki farklı paydaşlarla sürekli işbirliği içerisindedir. Bu durum, rehberleri zaman zaman farklı rollere sokabilir. Örneğin; seyahat acentası adına turun sorunsuz yürümesini sağlamak veya yerel halk ve turistler arasındaki dengeyi sağlayabilmek bir turist rehberinin rolleri arasındadır (Cetin \& Yarcan, 2017). Ancak, zaman zaman çatışmalar olabilmektedir. Elde edilen bulgulara göre, kadın turist rehberleri yerel satıcılar ve esnaflarla ilişkilerinde de bazı sorunlar yaşamaktadır. Örneğin;

“...Hanutçulardan hoşlanmıyorum ve onlarla diyalog kurmak benim en haz etmediğim şey...”. K.16

\section{Turistlerle ilgili sorunlar}

Turistik bir faaliyetin merkez noktası turistlerdir. Turistlerin ise en fazla zaman geçirdiği ve en yoğun ilişkide bulunduğu kişiler arasında turist rehberleri bulunmaktadır (Dumanlı \& Köroğlu, 2018). Mesleğin rollerini iyi bir şekilde yerine getiren turist rehberleri; destinasyon için iyi bir imaj algısı, seyahat memnuniyeti, yeniden ziyaret etme niyeti gibi pek çok olumlu sonuca vesile olur (Hwang \& Lee, 2019).

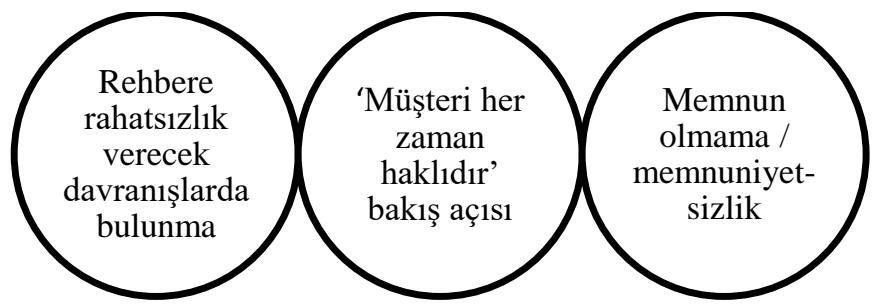

Şekil 5: Turistlerle yaşanan sorunlara ilişkin ortaya çıkan temalar

Hizmet ağırlıklı mesleklerde çalışanlar mesleğin getirisi olarak her koşulda gülümsemeye ve üstün hizmet vermeye çalışmaktadır. Ancak turist rehberleri her ne kadar turun iyi geçmesi için emek sarf etse de, bazen rehberden kaynaklı olmayan sorunlarla karşılaşma olasılığı da bulunmaktadır. Bu kapsamda turistlerden kaynaklı sorunlar, zaman zaman turist rehberlerinin duygusal açıdan yıpranmasina ve duygusal emek harcamasına neden olabilmektedir. Elde edilen bulgulara göre, tur esnasında rehberlere rahatsızlık verecek davranışta bulunma (örn. şahsi sorular yöneltilmesi), her koşulda haklı görülme beklentisi, haklı olsun veya olmasın hiçbir zaman memnun olmayan turistlerin varlığı gibi konular kadın turist rehberleri açısından yaşanan zorluklar olarak ortaya çıkmıştır. Örnek vermek gerekirse;

“...Şahsi sorular ve alakasız sorular beni ciddi yoruyor... Özel hayatımızdan bahsetmek istemiyoruz ama zorluyorlar. Tercihlerimiz, siyasi düşüncelerimiz, kişisel hayatlarımız vs. bu tarz şeyleri konuşmaktan pek hoşlanmıyorum açıkçası...”. K.6 
“... Müş̧terinin sizi hizmet veren olarak görmesi ve 'paramı verdim, ne istiyorsam onu yap' tavrından hoşlanmıyorum...”. K.7

“... Bazen misafirlerin memnuniyetsiz tavırlarından hoşlanmıyorum... Mesela canla başla tur yapıp, yă̆mur yă̆dĭ̆ zaman 'aa yă̆mur yă̆dl, memnun değiliz' gibi hiç bizimle alakası olmayan konulardaki sorunların bize yansıtılmasından hoşlanmıyorum ... ’. K.9

Sayılan dört kategorideki sorun ve zorlukların yanında sayıca nadir olsa da, bazı kadın turist rehberleri yasadışı rehberlik, kokartın kolay bir şekilde alınması, tur esnasında rehberin kontrolü dışında olayların yaşanması ve organizasyon aksaklıkları gibi sorunları da belirtmişlerdir. Bu kapsamda örnek olarak aşağıdaki ifadeler gösterilmektedir:

“...Sevmediğim galiba organizasyon bozuklukları. Mesela havalimanlarında yaşanan aksaklıklar...” K.19

“...Kokartın çok kolay alınabilir olmasından pek hoşlanmıyorum. Kokartı olan her insanın rehber vasfi taşıdı̆̆ına ben hiç inanmıyorum. Başka bir deneyim gerektiren bir iş gibi görüyorum ben rehberliği ve kokart almak için yeterlilikleri az buluyorum...”. K.16

\section{SONUÇ VE TARTIŞMA}

$\mathrm{Bu}$ çalışmada, kadın turist rehberlerinin yaşadığı sorunlar ve zorluklar tespit edilmiştir. Elde edilen bulgulara göre, kadın turist rehberlerinin sorunları önem derecesine göre; (i) cinsiyetten kaynaklı zorluklar, (ii) mesleğin doğası gereği yaşanan sorunlar, (iii) hizmet sağlayıcılar ile ilgili sorunlar ve (iv) turistlerle yaşanan sorunlar olarak ortaya çıkmıştır. Araştırmanın gerek teorik, gerekse pratik açıdan katkı sağladığı düşünülmektedir.

Turist rehberliği mesleğinin genel sorunları ve kadın çalışanların sorunlarının farklılaştığı göz önüne alınarak, özellikle kadınlara yönelik mesleki sorunların belirlenmesi araştırmanın teorik katkısını ortaya koymaktadır. Çünkü özellikle mesleki sorunlar ortaya konulurken kadın-erkek ayrımı yapılmaksızın, alan yazında daha çok genel sorunlar ortaya konulmuş (Batman, 2003; Karacaoğlu \& Sert, 2018; Karamustafa \& Kılıçhan, 2019; Büyüktepe vd., 2019) ve kadın çalışanların sorunları göz ardı edilmiştir. Dolayısıyla bu çalışma, kadın turist rehberlerine yönelik sınırlı olan alan yazına (Arslan \& Şimşek, 2018; Köroğlu vd., 2020; Alrawadieh vd., 2021) katkı sağlaması açısından önemlidir.

Araştırmada en çok, kadınların cinsiyetten kaynaklı sorunlar yaşadığı sonucuna ulaşılmıştır. Bu sonuç, benzer birçok çalışmanın bulgularıyla örtüşmektedir (Zengin vd., 2014; Arslan \& Şimşek, 2018; Köroğlu vd., 2020). Her ne kadar meslek, kadın işi ve erkek işi olarak ayrılmasa da, somut sorunların yaşandığı sonucuna ulaşılmıştır. Bu sorunların ortadan kaldırılmasında en önemli çözümlerden biri, turizm sektöründe yer alan tüm paydaşlara eğitim verilmesi ve ayrımın ortadan kaldırılmasına yönelik stratejilerin geliştirilmesidir. Yine kadınlara yönelik her türlü ayrım ve farklı davranışın meslek kanununca yaptırımlarının olması, olası sorunların azaltılmasında önemlidir. Bu noktada meslek odalarının kadını koruması ve Türkiye Turist Rehberliği Birliği ile işbirliği içerisinde olması, sorunların çözüme kavuşturulmasında tüm tarafların aktif rol oynaması sağlanmalıdır. Özellikle kadının ciddiye alınmaması, kadın diye yönetici olamayacağı izlenimi, kadın diye ekstra dikkatli davranma zorunluluğu gibi sorunların toplumca da çözüme kavuşturulması ve sonrasında mesleki açıdan uyarlanması gerekmektedir. Bu kapsamda, çeşitli eğitim programları ve akademik desteklerle toplumun bilinçlenmesi sağlanabilir. Yine kadın diye tecrübesiz olduğu yönündeki algıyı ortadan kaldırabilmenin yolu, kadının işini severek ve sahiplenerek yapmasıyla olabilir. Bu kapsamda kadın 
turist rehberlerinin gerek kişisel, gerekse mesleki motivasyonlarını yükseltmek amacıyla kadını destekleyici etkinlikler, kişisel gelişim ve kişisel başarı seminerleri düzenlenebilir.

Araştırmada mesleğin doğası gereği yaşanan zorluklardan da sıklıkla bahsedilmiştir. Bu kapsamda meslek; uzun çalışma saatleri olan, fiziksel güce ve duygusal emeğe dayanan bir meslektir. Ancak kadın turist rehberlerinin mesleki açıdan yıpranmalarını ve bu zorlu koşulların yol açacağı sorunları ortadan kaldırabilmenin bir yolu, seyahat acentalarının onlara örgütsel destek sağlaması, özel günleri kutlaması, başarılarını önemsemesi ve rehberini koruması ile mümkün olabilir. Yine bu kapsamda rehberlerin mesleki zorluklarını azaltabilmek için sosyal desteğin de arttırılması önemlidir. Bu kapsamda iş arkadaşlarından ve aileden gelebilecek destek çok önemlidir.

Araştırmada kadın turist rehberleri hizmet sağlayıcılar ile ilgili de çok fazla sorun yaşamaktadır. Bu kapsamdaki şikâyetler en çok seyahat acentalarından gelmektedir. Yukarıda da belirtildiği gibi turist rehberleri en çok seyahat acentalarıyla yakın işbirliği içerisindedir ve seyahat acentaları rehberini koruyarak, örgütsel destek sunarak olası sorunlar çözüme kavuşturulabilir. Yine otel işletmesi, yemeiçme işletmesi ve ulaştırma işletmesinde çalışan personelin eğitilmesi, yakın işbirliğinin nasıl kurulacağının anlatılması, kaba ve zorlayıcı tavırlar uygulayanlara çeşitli yaptırımlar uygulanacağının belirtilmesi (örn. işten uzaklaştırma) bu sorunların çözümü için oldukça önemlidir.

Sonuç olarak, bu çalışma kadın turist rehberlerinin sorunlarını araştırmaktadır. Ancak her araştırmada olduğu gibi bu araştırmanın da çeşitli kısıtları bulunmaktadır. Araştırılan örneklem sayısının arttırılması, daha fazla bilgi edinilmesi açısından önemli olabilir. Dahası, kadın turist rehberlerinin sorunlarını ortaya koymak adına yapılan bu nitel araştırmanın yanı sıra nicel araştırmalar veya karşılaştırmalı analizlerle olası sorunlar daha kapsamlı olarak tespit edilebilir. $\mathrm{Bu}$ araştırma, kadın turist rehberleriyle ilgili sınırlı olan alan yazının genişletilmesi için bundan sonraki araştırmalara bir çağrı niteliğindedir.

\section{KAYNAKÇA}

Ababneh, A. (2017). Tourist guides and job related problems, analysis and evidence from Jordan. Journal of Quality Assurance in Hospitality \& Tourism, 18(2), 200-217.

Akdu, U., \& Akdu, S. (2016). Duygusal emek ve iş stresinin tükenmişlik üzerindeki etkileri: Profesyonel turist rehberleri üzerinde bir araştırma, Journal of International Social Research, 9(47), 1142-1152.

Alrawadieh, Z., \& Demirdelen Alrawadieh, D. (2020). Sexual harassment and wellbeing in tourism workplaces: The perspectives of female tour guides. In Vizcaino, P., Jeffrey, H., \& Eger, C. (Eds). Tourism and gender-based violence: Challenging inequalities (pp. 80-92). CABI.

Alrawadieh, Z., Cetin, G., Dincer, M. Z., \& Istanbullu Dincer, F. (2020). The impact of emotional dissonance on quality of work life and life satisfaction of tour guides. The Service Industries Journal, 40(1-2), 50-64.

Alrawadieh, Z., Demirdelen Alrawadieh, D., Olya, H., Erkol Bayram, G., \& Kahraman, O. C. (2021). Sexual harassment, psychological well-being, and job satisfaction of female tour guides: The effects of social and organizational support, Journal of Sustainable Tourism, http://doi.org/10.1080/09669582.2021.1879819

Ap, J., \& Wong, K. K. (2001). Case study on tour guiding: Professionalism, issues and problems. Tourism Management, 22(5), 551-563. 
Aracı, Ü. E., \& Koçak, N. (2014). Dezavantajlı bireylerin turizmde istihdamı: İnsan kaynakları yöneticilerinin alg1, görüş ve deneyimlerinin incelenmesi. Gazi Üniversitesi Turizm Fakültesi Dergisi, 2, 191-205.

Arslan, A., \& Şimşek, G. (2018). Kadın turist rehberlerinin yaşadıkları mesleki sorunlar: Aydın turist rehberleri örneği. Journal of Travel \& Tourism Research, 13, 23-49.

Batman, O. (2003). Türkiye'deki profesyonel turist rehberlerinin mesleki sorunlarına yönelik bir araştırma. Bilgi Sosyal Bilimler Dergisi, 2, 117-134.

Berg, B. L. (2001). Qualitative research methods for the social sciences. 4. Bask1, Boston, Ma: Pearson Education Company.

Büyüktepe, H. S., Gökdemir, S., \& Korkmaz, H. (2019). Turist rehberlerinin sorunları üzerine nitel bir araştırma: Çanakkale örneği. Journal of Travel and Tourism Research, 14, 94-117.

Cave, P., \& Kilic, S. (2010). The role of women in tourism employment with special reference to Antalya, Turkey. Journal of Hospitality Marketing \& Management, 19(3), 280-292.

Cetin, G., \& Yarcan, S. (2017). The professional relationship between tour guides and tour operators. Scandinavian Journal of Hospitality and Tourism, 17(4), 345-357.

Chen, J., \& Chang, T. C. (2020). Touring as labour: Mobilities and reconsideration of tour guiding in everyday life. Tourism Geographies, 22(4-5), 813-831.

Dinçer, M. Z., \& Demirdelen, D. (2019). Turist rehberliğinin tarihsel gelişimi. In: Zengin B., Erkol Bayram, G., \& Batman, O. (Eds). Turist Rehberliği Meslĕ̆i (Dünü-Bugünü-Yarını) (pp. 1-15), Ankara: Detay Yayıncılık

Dinçer, M. Z., \& Alrawadieh, Z. (2017). Negative word of mouse in the hotel industry: A content analysis of online reviews on luxury hotels in Jordan. Journal of Hospitality Marketing \& Management, 26(8), 785-804.

Dumanlı, Ş., \& Köroğlu, Ö. (2018). Turist rehberlerinin stresle başa çıkma tarzları ile mizah tarzları arasındaki ilişkinin belirlenmesi, Journal of Yaşar University, 13(52), 328-342.

Elo, S., \& Kyngäs, H. (2008). The qualitative content analysis process. Journal of Advanced Nursing, 62(1), 107-115.

Ferguson, L., \& Alarcon, D. M. (2015). Gender and sustainable tourism: Reflections on theory and practice. Journal of Sustainable Tourism, 23(3), 401-416.

Figueroa-Domecq, C., Pritchard, A., Segovia-Pérez, M., Morgan, N., \& Villacé-Molinero, T. (2015). Tourism gender research: A critical accounting. Annals of Tourism Research, 52, 87-103.

Glaser, B. G., \& Strauss, A.L. (1967). The discovery of grounded theory: Strategies for qualitative research. New York: Aldine Publishing Company.

Güzel, F. Ö., Türker, A., \& Şahin, İ. (2014). Profesyonel turist rehberlerinin algıladıkları mesleki engelleri belirlemeye yönelik bir araştırma. Gazi Üniversitesi Turizm Fakültesi Dergisi, 2, 173-190.

Hall, D., Swain, M. B., \& Kinnaird, V. (2003). Tourism and gender: An evolving agenda. Tourism Recreation Research, 28(2), 7-11. 
Hwang, J., \& Lee, J. (2019). Relationships among senior tourists' perceptions of tour guides' professional competencies, rapport, satisfaction with the guide service, tour satisfaction, and word of mouth. Journal of Travel Research, 58(8), 1331-1346.

Karacaoğlu, S., \& Sert, A. N. (2018). Turist rehberlerinin mesleki sorunları üzerine bir araştırma: Kapadokya örneği. Journal of Tourism and Gastronomy Studies, 6(3), 81-99.

Karamustafa, K., \& Kılıçhan, B. (2019). Delphi yöntemi ile profesyonel turist rehberliği mesleğine ilişkin sorunların tespit edilmesi. Afyon Kocatepe Üniversitesi Sosyal Bilimler Dergisi, 21(4), 13481365.

Koc, E. (2020). Do women make better in tourism and hospitality? A conceptual review from a customer satisfaction and service quality perspective. Journal of Quality Assurance in Hospitality \& Tourism, 21(4), 402-429.

Köroğlu, Ö., Yıldırım, H. U., \& Kılıç, A. (2020). Kadın turist rehberlerinin mesleki sorunlarının belirlenmesi. Mehmet Akif Ersoy Üniversitesi Sosyal Bilimler Enstitüsü Dergisi, 31, 26-40.

Liljeblad, J. (2020). Tour guides and the transnational promotion of human rights: Agency, structure and norm translators in responsible travel. Tourist Studies, 20(3), 314-335.

Lin, W. R., Chen, H. M., \& Wang, Y. C. (2019). Work-Family conflict and psychological well-being of tour leaders: The moderating effect of leisure coping styles. Leisure Sciences, 1-22. doi $=10.1080 / 01490400.2019 .1671253$

Mackenzie, S. H., \& Kerr, J. H. (2013). Stress and emotions at work: An adventure tourism guide's experiences. Tourism Management, 36, 3-14.

Mackenzie, S. H., \& Raymond, E. (2020). A conceptual model of adventure tour guide well-being. Annals of Tourism Research, 84, 1-14.

Min, J. (2014). The relationships between emotional intelligence, job stress, and quality of life among tour guides. Asia Pacific Journal of Tourism Research, 19(10), 1170-1190.

Muñoz-Bullón, F. (2009). The gap between male and female pay in the Spanish tourism industry. Tourism Management, 30(5), 638-649.

Neuman, W. (2003). Social research methods: qualitative and quantitative approaches, Boston: Allyn \& Bacon.

Nyahunzvi, D. K., \& Njerekai, C. (2013). Tour guiding in Zimbabwe: Key issues and challenges. Tourism Management Perspectives, 6, 3-7.

Patton, M. Q. (1990). Qualitative evaluation and research methods. Newbury Park, CA: Sage.

Ram, Y. (2018). Hostility or hospitality? A review on violence, bullying and sexual harassment in the tourism and hospitality industry. Current Issues in Tourism, 21(7), 760-774.

Segovia-Pérez, M., Figueroa-Domecq, C., Fuentes-Moraleda, L., \& Muñoz-Mazón, A. (2019). Incorporating a gender approach in the hospitality industry: Female executives' perceptions. International Journal of Hospitality Management, 76, 184-193.

TUREB, Türkiye Turist Rehberleri Birliği (2021). Erişim Tarihi Şubat 1, 2021, http://tureb.org.tr/tr/RehberIstatistik/ 
Demirdelen Alrawadieh (2021), Johti, 3(1), 1-15

TÜIK, Türkiye İstatistik Kurumu (2021). Erişim Tarihi Şubat 5, 2021, https://data.tuik.gov.tr/Bulten/Index?p=Istatistiklerle-Kadin-2019-33732

Umutlu, S., \& Öztürk, M. (2020). İş yaşamında kadın ve karşılaştığı sorunlar. Süleyman Demirel Üniversitesi İktisadi ve İdari Bilimler Fakültesi Dergisi, 25(3), 297-306.

United Nations Sustainable Development Goals (2021). Erişim Tarihi Şubat 2, 2021, https://sdgs.un.org/goals

Wang, H., \& Xu, H. (2018). Gender strategies at work: Informal female tour guides in Yangshuo West Street. Journal of China Tourism Research, 14(4), 524-540.

Wong, J. Y., \& Wang, C. H. (2009). emotional labor of the tour leaders: An exploratory study. Tourism Management, 30(2), 249-259.

Yagil, D. (2008). When the customer is wrong: A review of research on aggression and sexual harassment in service encounters. Aggression and Violent Behavior, 13(2), 141-152.

Yazıt, H., \& Demirdelen, D. (2018). Turizm sektöründe cam tavan sendromu ve kadın. In Erkol Bayram G., Bayram A. T., \& Altıöz Sürücü, Ö. (Eds). Turizm ve Kadın (pp. 155-162). Ankara: Detay Yayıncılık

Yetiş, Ş. A., \& Çalışkan, N. (2020). Turizm sektöründe kadın istihdamı: mevcut duruma ilişkin bir değerlendirme. Manisa Celal Bayar Üniversitesi Sosyal Bilimler Dergisi, 18(3), 105-119.

Zengin, B., Erkol, G., \& Eker, N. (2014). Rehberlik mesleğinde bir engel olarak cinsiyet ayrımcılığı: Bayan turist rehberleri üzerine bir araştırma. In Kılıçlar, A. (Eds.), 15. Ulusal Turizm Kongresi Bildiri Kitabı (pp. 511-524). Ankara: Gazi Üniversitesi.

\section{Yazar(lar) Hakkında/About Author(s)}

Derya DEMIRDELEN ALRAWADIEH / deryademirdelen@ayvansaray.edu.tr

Gaziosmanpaşa Üniversitesi Zile Dinçerler Turizm ve Otel İşletmeciliği Yüksekokulu'ndan mezun oldu (2009). Yüksek lisans derecesini Sakarya Üniversitesi Turizm İşletmeciliği Anabilim dalından (2013), doktora derecesini İstanbul Üniversitesi Turizm İşletmeciliği Anabilim dalından (2021) aldı. İstanbul Ayvansaray Üniversitesi’nde çalışmaya başladı (2013). Halen İstanbul Ayvansaray Üniversitesi Plato Meslek Yüksekokulu'nda görev yapmaktadır.

Adres: İstanbul Ayvansaray Üniversitesi, Plato Meslek Yüksekokulu, Zeytinburnu / İSTANBUL 